\title{
The Impact of Total Quality Management Multidimensional on Non-Financial Organizational Performance: An Empirical Investigation of Saudi Commission for Tourism and National Heritage Hotels
}

\author{
Dr. Abdullah Yahia Moqbile Ahmed \\ Department of Management \\ Agency of deanship of Community Service and Continuing Learning-Shrourah, \\ Najran University \\ Saudia Arabia
}

\begin{abstract}
This examination experimentally explores the most powerful components of all out total quality management (TQM) (top management support, customer focus, employees' participation, training and education, continuous process improvement, strategic planning, effective communication, and decision-making based on data and information ) on the non-financial organizational performance measurements (job satisfaction, organizational commitment, and employee's creativity). The investigation involved 121 employees from different hotels, which are classified within the Saudi Commission for Tourism and national Heritage (SCTH) in Najran Region. Using multiple regression analysis, findings indicated that Effective communication followed by Top management support, Continuous process improvement, Employee participation, Decision-making based on information, Strategic planning, Training and education and finally by customer focus. Thusly, this current investigation's results can be prescribed to expand acknowledgment of the significance of human resource metrics in organizational performance.
\end{abstract}

Keywords: Total quality management dimension, Organizational performance, Saudi Commission for Tourism and national Heritage.

\section{Introduction}

TQM is a significant way of thinking and arrives at a high level of consideration in improving organizational effectiveness. It is a set of principles that gives the foundation of continuous improvement in firm, in each part of each process, each level and every exercising ought to be the fantastic target at large (Oakland,1989). Its guiding standards help the firms to produce higher exceptional products, reduces costs, will increase purchaser and employee satisfaction and improves organizational performance (Ngambi, \&Nkemkiafu, 2015). TQM when effectively helps in fulfillment sustainable competitive advantage (Reed, Lemak, \& Mero, 2000). TQM is a greatly recognized management philosophy, and has grown to be the key slogan as corporations attempt for competitive advantage in markets (Al-Qudah, 2012). A lot of researches investigate the impact of TQM on organizational performance. Reed et al., (2000). examines TQM can generate a sustainable competitive advantage. Previous practical studies mentioned that TQM implementation does have a significant positive influence on organizational performance, as showed in the case of small and medium enterprises, across set of manufacturing firms small and medium-sized, manufacturing and service companies (Singh, Kumar, \& Singh, 2018). A comprehensive review, of past empirical studies on TQM and performance relationshipare diverse (Joiner, 2007; Talib, Rahman, \& Qureshi, 2013; Ngambi, M., T., \&Nkemkiafu, A. G. (2015). Some of these studies indicate failure of TQM in improving performance. The previous finding recommending further research to discover their comparative role the relationship between TQM constructs and organizational performance. There is limited of empirical investigation that precisely identifies the serious multidimensional of TQM as the forecaster of organizational performance. Although, companies are increasingly applying innovative performance measurement system to assess taking decision performance and to follow nonfinancial metrics such as job satisfaction, organizational commitment, and employees creativity (Abu Ziada, 2011). Ittner and Larcker (1996), Jusoh, Ibrahim, and Zainuddin (2008), and Shah (2009) discussed that non-financial performance measures are more promising than financial measures consequently managers must rely on strongly on them as a choice that will assistance their firms in future. Furthermore, Nayla, and Ridzuan (2014) indicated that the direct effect of the use of non-financial measures on organization performance is significant.

The local context in a considerable sector gives us further motivation to identify the most critical constructs of TQM in this regard. In contextual perspective there has been little bet critically investigate the relationship of TQM multidimensional and organizational performance in hospitality and tourism sectors anywhere in the world let alone Saudi Arabia. 
The Middle East's realty services supplier forecasting constanted development in the hotel sector over this country, due to the steady increase of tourists (Savills, 2016). Actually, as reported by world travel and tourism council (2019) the last annual statistics, travel and tourism represents for 9.4\% KSA's total GDP, with travelers expense rising by $10.5 \%$ annually $(\$ 14.8 \mathrm{bn})$. It addition that, as the country diversities its economy on line with the vision 2030, international arrivals will be increasing on rate by $4 \%$ per annum achieving numbers of $22.1 \mathrm{~m}$ by 2025. That is why the existing study especially considers on hotel industry in Saudi Arabia where the international market is of extreme importance. TQM principles are considered more relevant to service firms as compared to manufacturing firms. Therefore, it is of further significance to investigate the importance of TQM measurements on performance of this sector that may assistance the workers of hotels as well as other services sectors to improve their performance.

This is the maiden empirically examination on TQM -performance relationship in service sector of a developing country like Saudi Arabia. This study aims at: a) examining the relationship between TQM multidimensional and nonfinancial organizational performance; b) identify which TQM measurements is a major predictor of performance of Saudi's hotels services Such an empirical determination on the relationship of TQM multidimensional toward nonfinancial organizational performance in hotels, Saudi Commission for Tourism and National Heritage (SCTH) belong to Najran Region. The paper attempts to extend the present research by identifying serious variables of TQM with the assistance of empirical data to clarify TQM - non-financial performance relationship.

\section{Literature Review and Hypothesis Development}

\subsection{Total Quality management multidimensional}

Several investigators identify that the most influence constructs of TQM are those that are hard, and also known as the soft variables consisting of top-management commitment, customer focus, training and education, continuous improvement and innovation, supplier management, employee involvement, information and analysis, process management, quality systems, benchmarking, quality culture, human resource management, strategic planning, employee encouragement, teamwork, communication, and Product and service design as these dimensions have a direct effect on in both manufacturing and service industries performance ( Talib, Rahman, \& Qureshi, 2013). As stated by Nitin, Dinesh, and Paul (2011) the most best ten critical success factors of TQM implementation are Training, top management commitment and customer satisfaction. Shenawy, Baker, \&Lemak, (2007) debate that little bit research clarify the key dimensions of TQM. As a consequence of this inconsistency in in previous research it is hard to identify the precise dimensions of TQM (Hoang, Igel, \&Laosirihongthong, 2006). Nevertheless majority of the researchers approve that the most substantial dimensions of TQM are top management support, customer focus, employee participation, training and education, continuous process improvement, strategic planning, effective communication, and decision-making based on data and information (Corbett \&Rastrick, 2000; Hackman \&Wageman 1995; Lewis, Pun \&Lalla, 2005; Ooi, Arumugam., Safa, \& Bakar, 2007; Ramli, Zen, Mustafa,. \&Yusoff, 2017; Sadikoglu\&Zehir, 2010; Sayyad, 2017). In this paper TQM is addressed as multidimensional construct to investigate its effect on non-financial organizational performance.

\subsubsection{Top Management Support}

The ISO 9001 standard defines top management as a person or group of people who direct and control an organization at the highest level (ISO, 2000). The main objective is to create an environment where people are fully involved and in which a quality management system can operate effectively and make recommendations to achieve this objective. Top management support to quality management is an absolute precedence for preparing organizational culture before TQM practices can be implemented (Antony, Leung, Knowles, \& Gosh, 2002). According to Lewis, Pun and Lalla (2005) top management support or commitment can be divided into four factors for effective implementation of TQM. These factors are strategy finalization, resource based strategy, environmental focus, and quality culture. Top management could use resource based strategy to get a "sustained" competitive advantage if their resources (or capabilities) are valuable, rare among competitors, imperfectly imitable and not easily substitutable (Barney, 1991). Based on the above literature we propose the first hypothesis in hotel sector of a developing country like Saudi Arabia.

H1: Top management support positively affects Non-financial Organizational Performance.

\subsubsection{Customer Focus}

Firms have to knowing about customer requirements and reacting quickly and positively to customer demands and measure customer satisfaction through TQM implementation (Zakuan, Yusof, Laosirihongthong, \&Shaharoun, 2010; Zhang, Waszink, \&Wijngaard, 2000). By keeping significant degree of customer satisfaction by significant quality and innovative products and services can create a competitive edge for the firm (Hooley, Fahy, Greenley, \& Beracs2003). 
According to the findings from Hackman and Wageman (1995), getting information about customer is one of the common way used TQM implementation practices to enhance quality performance of the organization. Therefore, the next hypothesis relate to customer focus and Non-financial Organizational Performance:

H2: Customer focus positively affects Non-financial Organizational Performance.

\subsubsection{Employee Participation}

Deming declared that participation of workforce at all level leads to enhance the quality of the product or service at the moment or in the future. Even though non-managerial employees could make important participations when they are involved in quality improvement processes, decision making processes, and policy making issues (Sadikoglu\&Zehir, 2010; Ooi , Arumugam., Safa, \& Bakar, 2007). Increased employee's participation in the overall quality strategy brings spread of information and knowledge and contributes to the ability of the organization for resolving problems (Schalk, \&Dijk, 2005). For employees, a significant aim of TQM is the broadening of work responsibilities. Organizations should utilize all workers' skill and abilities to get business performance. Accordingly, the hypothesis is as follows:

H3: Employee participation positively affects Non-financial Organizational Performance.

\subsubsection{Training and education}

Training and education widespread the knowledge of continuous improvement and innovation in service process to gain full benefits and business excellence. Talib and Rahman (2010) reported the significant way of training and education in preserving high quality level within the service industry. Further, Sayyad (2017) found that training and education are significantly positively associated with Palestinian manufacturing and service firms' quality improvement practice.Therefore, the next hypothesis relate to Training and education and Non-financial Organizational Performance:

H4. Training and education positively affects Non-financial Organizational Performance.

\subsubsection{Continuous process Improvement}

Continuous process improvement is the main target of any services means searching for endless enhancements and improving processes to discover new or improved ways in the operation of changing inputs into beneficial outputs. It assistances in decreasingoperation volatility that way continuously enhancing the output performance (Sadikoglu and Zehir, 2010). TQM tactics is an administrative ideology that attempt to satisfy customers by continuous improvement activities at all organizational levels and functions by involving all the stakeholders (Benavent, Ros, \& MorenoLuzon, 2005). Corbett and Rastrick (2000) emphasized that in TQM, the most effective way to enhance organizational performance is to continuously enhance the performance activities. Therefore, this study proposes the fifth hypothesis in a new context.

H5: Continuous process improvement positively affects Non-financial Organizational Performance.

\subsubsection{Strategic planning}

The strategic planning plying the critical role that improve organizational performance (Ferdinand, 2002).This goes back to the fact that strategy planning is a comprehensive preparation that demonstrates the competitive situation of the company (Quinn \&Goold, 1990). Strategic planning include the development and deployment of plans, improve relationships with customers, suppliers, and business partners and assistances in obtaining long and short term goals through participative planning (Teh, Yong, Arumugam,. \&Ooi, 2009). Consequently, Ramli, Zen, Mustafa,. \&Yusoff, (2017), discovered that appositive relationship between the strategic planning and organizational performance in the public sector in Aceh Indonesian. Therefore, the next hypothesis attempts to find a relationship between strategic planning and Non-financial Organizational Performance.

H6. Strategic planning positively affects Non-financial Organizational Performance.

\subsubsection{Effective communication}

communication indicate to the style of exchange information between employees themselves inside the organization (Ooi, Arumugam, Safa, and Bakar, 2007), Previous researchmentioned that effective communication influence the organization to move consistently towards employees involvement customer satisfaction and enhances organization performance (Ooi, et al. 2007, Yusuf, Gunasekaran,. \& Dan, 2007). Kibe (2014) concluded that for any organizational performance to be influential, an open communication environment should be encouraged. When employees of the firms are free to share feedback, ideas and even criticism at every level, it increases performance. Bery, Otieno, Waiganjo\& Njeru (2015) found that effective communication in Kenya's horticultural sector among the employees will lead to improve the performance and efficiency for the organizations . Based on the above Investigations the following hypothesis was proposed: 
H7. Effective communication positively affects Non-financial Organizational Performance.

\subsubsection{Decision-Making Based on Data and Information}

TQM is an information comprehensive management. Information plays a critical role as all quality development activities are based on knowledgeable decision-making (Terziovski, Sohal\& Samson, 1996). A company's database must be compatible and cover all serious areas such as customers, suppliers, employees and projects/processes (Flynna, , Schroederb, \&Sakakibara, 1994).As managing quality generates a lot of data, it is very necessary to decided what kinds of data are deserve keeping and how to arrange them into an easily accessible place. The databases must have capabilities to facilitate the handling of different data and in-depth analysis to meet the information requirements of each level (strategic, tactical and operational) of decision-making activities (Zahedi, 1998). Therefore, the following hypothesis is put forward:

H8: Decision-Making Based On data and Information positively affects Non-financial Organizational Performance.

\subsection{Organizational Non- Financial Performance}

Generally, performance is the indication of accomplishment of organizational objectives. Organizational performance is defined as the output of the firm's operations or achievements of firm's goals. Venkatraman and Ramanujam (1986) divide the business performance in three measurements: these are operational, financial and organizational effectiveness. Whereas operational or non-financial performance includes product quality, market share, market effectiveness and new product introduction; financial performance includes the profitability and sales growth; and organizational effectiveness is an extent to which organizations achieve their effectiveness. According to Abu Ziadeh, (2011) organizational non-financial performance has dimensions associated with of human resource performance. It covers job satisfaction, organizational commitment, and employee's creativity which are explained in details below:

\subsubsection{Job Satisfaction}

Employee satisfaction has a positive effect on business performance (Jun, Cai, \& Shin, 2006). Employee satisfaction is an emotional situation resulting from experiences of effort (Locke and Schweiger, 1979). They emphasized that the conducive values contributing to job satisfaction which are mentally challenging work, personal interest, work that is not too physically exhausting, pay for performance, working condition, high self-esteem and organizational support. Besides that, according to Luthans, (1989), there are three aspects in employee satisfaction which are emotional response to the work environment, the relationship between expectation and outcomes and satisfaction with pay. When employee satisfaction can be reached, the employee loyalty level will also increase and reduce the turnover rate (Jun et al., 2006). According to MosammodMahamudaParvin, (2011), there are six factors that contributing to the employee satisfaction which are level of work condition, level of pay and promotion, level of fairness, level of job security, level of teamwork and level on relationship with immediate supervisor.

\subsubsection{Organization Commitment}

Organization commitment can be divided into 3 terms of its nature (Cheng \&Kalleberg, 1996): (1). Willingness to undertake business interests that benefit organization, (2). Strong desire to maintain membership in the organization. (3) Strong belief and acceptance of the organization's goals and values. Engagement and loyalty is greatly affected by how much work is charged to employees in accordance with their expectations (Babakus, 1996). In a study conducted Benkhoff (1997), organizational commitment plays an important role for the improvement of good performance and neglect of commitment to the organization will lead to a loss.

\subsubsection{Employee's Creativity}

Creativity is explained as a design in which the employee make such innovative construction in which the work related problems are resolved in rightful manner with step by step process, some explain it as the ability of the individuals how they can develop useful solution to meet the challenges and overcome the problem them self individually (Amabile, 1988; Young, 1994).It is mostly involved in the generation of change in product, due to working in team the employee are continuously engaged in learning new knowledge, skills which are the necessary requirements needed by the organization from the employee so they can accomplish timely goals (Amabile, 1988, 1996).

A creative employee is one who can come up with new suggestions/ideas for the services to be constructed, the flood of the communication and understanding it in the same way which would affect the work done by the employee during his working hour (Amabile, 1988). He is one who has the ability to be percipient of the organization and must be sensitive so that he can challenge the problem, he must have an acute mind so he is able to remember his task for long time, and he must be adaptive, it is because due to globalization there is quick change in the technology as well the culture so a creative employee would be one who is able to adapt all the changes before time, in this way he would be dubbed as creative (Evans, 1991). 
The above hypotheses are summarized and presented in the conceptual model below :

\begin{tabular}{|c|}
\hline TQM multidimensional constructs \\
\hline
\end{tabular}

\begin{tabular}{|c|}
\hline $\begin{array}{c}\text { Non-financial Organizational } \\
\text { Performance }\end{array}$ \\
\hline
\end{tabular}

\begin{tabular}{|l|l|}
\hline Top Management Support & $\longrightarrow$ \\
\hline Customer Focus & $\longrightarrow$ \\
\hline Employee Participation & $\longrightarrow$ \\
\hline Craining and Education4 & $\longrightarrow$ \\
\hline Strategic Planning & $\longrightarrow$ \\
\hline Effective Communication & $\longrightarrow$ \\
\hline Decision-Making Based on data and Information & $\longrightarrow$ \\
\hline
\end{tabular}

\begin{tabular}{|l|}
\hline Job Satisfaction \\
\hline Organization Commitment \\
\hline Employee's Creativity \\
\hline
\end{tabular}

3. Methodology

Fig. 1. The conceptual model of the research.

\subsection{Sample Data Collection}

This study specifically targeted employees operating in all categories of hotels from 1 to 5 stars hotels, in Najran region, which are classified within the Saudi Commission For Tourism and National Heritage (SCTH). There are 33 hotels in the Najran region (SCTH, 2018). The choice of Najran region as the study area was motivated the revelations by SCTH (2018), these categories of hotels are dominant in Najran region .185questionnaires were distributed among the employees of those hotels. The sampling procedure employed was simple random sampling technique and 121 questionnaires were returned with a response rate of $97.8 \%$. The researchers went to each hotel and distributed the questionnaire personally. The respondents were briefed on the study objectives and they were given the guidelines in answering the questionnaires.

The demographic details of the respondents are displayed in the Table 1. From the results, 44 (36.4\%) were less than 25 years; $73(60.3 \%) 35-26$ years; were $4(3.3 \%)$ were $36-45$ years; and there is no any respondents were more than 46 years old. The gender distribution indicated that $121(100 \%)$ were males, and $0(0 \%)$ were females. In terms of their educational background, 75 (62\%) had Senior High School education; 42 (34.7 \%) had Bachelor degree; and $43.3 \%)$ had Master's degree. Furthermore, their income level indicated that $6(5 \%)$ were less than 3000 Saudi Riyal; 78 (64.5\%) were 3000 -5000 Saudi Riyal; 37 (30.6\%) were 5000 -7000 Saudi Riyal, and no of them reach their income more than 7000 Saudi Riyal .

Table 1:Demographic background of the respondents

\begin{tabular}{|l|c|c|c|}
\hline Demographic Details & & Frequency & Percentage \\
\hline & & & \\
\hline Gender: & Male & 121 & 100 \\
\hline & Female & 0 & 0 \\
\hline Age (in years): & & & \\
\hline & Less than 25 years & 44 & 36.4 \\
\hline & 26 years - 35 & 73 & 60.3 \\
\hline & $36-45$ years & 4 & 3.3 \\
\hline & 46 years and above & 0 & 0 \\
\hline Education: & & & 62 \\
\hline & Senior High School & 75 & 34.7 \\
\hline & Bachelor Degree & 42 & 3.3 \\
\hline & Master's Degree & 4 & 5 \\
\hline Income: & & & 64.5 \\
\hline & Less than 3000 SAR & 6 & 30.6 \\
\hline & 3000 -5000 SAR & 78 & 0 \\
\hline & 5000 -7000 SAR & 37 & 0 \\
\hline
\end{tabular}




\subsection{Measures}

\subsubsection{Total Quality management multidimensional}

TQM multidimensional contains eight major elements which are top management support, customer focus, employee participation, training and education, continuous process improvement, strategic planning, effective communication, and decision-making based on information. The elements in this study were applied from different studies such as: Flynn et al. (1994), Black and Porter (1996), Ahire, Golhar, and Waller, (1996), Al-Damen, (2017). The instrument was modified by consulting with academicians and quality experts, and was initiallyvalidated through a pilot survey before it was actually used for primary data collection. Sample answered questions on a five point Likert scale ranging from 1 (strongly disagree) to 5 (strongly agree) through four items for top management support, three items for customer focus, five items for employee participation, five items for training and education, five items for continuous process improvement, five items for strategic planning, four items for effective communication, and four items for decision-making based on information.

\subsubsection{Organizational Non- Financial Performance}

Organizational Performance (dependent variable) was measured with four items which were developed by Abu Ziadeh, (2011). The items were as the following: job satisfaction (7 items), organizational commitment (7 items), Employee's creativity (6 items), and Extra-role behavior (5 items). It was derived consequently from Sherisheer, (2000), (Melhim, 2006); (Porter, 1979); (Zhou \& George, 2001); and (Pearce \&Gregersen, 1991). All these items are measured by using questions use 5-Likert interval scales measurement (5-strongly agree and 1-strongly disagree).

However, all the constructs (as well as organizational performance) are first time used in our context i.e. Saudia's hotel sector. According to Hair, Yoseph, Rolph, Anderson, and Black (1998) the cutoff point for Cronbach's Alpha is greater than 0.60. It can be perceived that the Alpha values of all the scales are greater than the minimum level of acceptance. The reliability coefficients for are Top management support, customer focus, employee participation, training and education, continuous process improvement, strategic planning, effective communication, and decision-making based on data and information. and organizational performance are $0.82,0.850,0.841,0.855,0.844,0.848,0.831$, and 0.835 respectively.

\section{Data Analysis and Result}

The data was analyzed using descriptive statistics, Pearson Moment correlation and Linear Multiple regression with the aid of SPSS version 22.0. Descriptive statistics were used to analyze the demographic variables of the respondents and also for testing some assumptions underlying regression analysis such as normal distribution. Pearson correlation was used for establishing preliminary relationship between the study variables. Regressions were used to test the direct effect of TQM Dimensions on Organizational Performance. Harman's one-factor test was used for the investigation of common method bias (Podsakoff, MacKenzie, Podsakoff, \& Lee, 2003). The basic supposition of this technique is that; "if a substantial amount of common method variance is present, a single factor will emerge from the factor analysis or the majority of the covariance will be concentrated in one of the factors" (Podsakoffet al., 2003). The analysis showed that the highest variance explained by a single factor was $20.45 \%$, thereby indicating no significant concerns for existence of common method bias. Normality and multicollinearity were also checked. Using the criteria of absolute values of less or greater than 1.96 or $-1.96, p<0.05 ; 2.58$ or $-2.58, p<0.01$, and 3.29 or $-3.29, p<0.001$ (Field, 2009), overall all the variables were normally distributed at $5 \%$ level of significance.

Multicollinearity was also investigated using variance inflation factor (VIF). The investigation revealed a VIF of 4.04 as the independent variable (s) were used on the dependent variable. This was well within the minimum threshold of not more than 10. Aside, the correlations between the independent variables (see Table 2) were less than 0.70 (Tabachnick\&Fidell, 2007). Hence, it is concluded that there were no serious multicollinearity issues. 
Table 2: Descriptive and person correlation analysis

\begin{tabular}{|c|c|c|c|c|c|c|c|c|c|c|c|}
\hline Variables & Mean & SD & 1 & 2 & 3 & 4 & 5 & 6 & 7 & 8 & 9 \\
\hline $\begin{array}{c}1 \text {-Top } \\
\text { management } \\
\text { support }\end{array}$ & 4.34 & 0.66 & 1 & & & & & & & & \\
\hline $\begin{array}{l}\text { 2.Customer } \\
\text { focus }\end{array}$ & 4.52 & 0.78 & $.583^{\prime \prime}$ & 1 & & & & & & & \\
\hline $\begin{array}{l}\text { 3.Employee } \\
\text { participation }\end{array}$ & 3.86 & 0.8 & $.621 "$ & $.441 "$ & 1 & & & & & & \\
\hline $\begin{array}{l}\text { 4.Training and } \\
\text { education }\end{array}$ & 3.38 & 0.95 & $.652^{\prime \prime}$ & $.523^{\prime \prime}$ & $.371 "$ & 1 & & & & & \\
\hline $\begin{array}{l}\text { 5.Continuous } \\
\text { process } \\
\text { improvement }\end{array}$ & 3.82 & 0.82 & 0.148 & 0.128 & $.320 "$ & .347" & 1 & & & & \\
\hline $\begin{array}{l}\text { 6.Strategic } \\
\text { planning }\end{array}$ & 4 & 0.82 & 0.069 & $.202^{\prime}$ & $.405 "$ & $.184^{\prime}$ & $.535^{\prime \prime}$ & 1 & & & \\
\hline $\begin{array}{l}\text { 7.Effective } \\
\text { communication }\end{array}$ & 4.53 & 0.59 & $.350^{\prime \prime}$ & $.375^{\prime \prime}$ & $.408 "$ & $.240^{\prime \prime}$ & $.747 "$ & .642" & 1 & & \\
\hline $\begin{array}{l}\text { 8.Decision- } \\
\text { making based } \\
\text { on information }\end{array}$ & 4.24 & 0.81 & $.317^{\prime \prime}$ & $.310^{\prime \prime}$ & $.342 "$ & $.190^{\prime}$ & $.508 "$ & $.589 "$ & $.745^{\prime \prime}$ & 1 & \\
\hline $\begin{array}{l}\text { 9.Non-financial } \\
\text { Organizational } \\
\text { Performance }\end{array}$ & 4.12 & 0.47 & $.647^{\prime \prime}$ & $.353^{\prime \prime}$ & $.595 "$ & .403" & $.606 "$ & .494" & $.771 "$ & $.578 "$ & 1 \\
\hline
\end{tabular}

** Significant at $0.01(1 \%) *$ Significant at $0.05(5 \%)$

The descriptive and Pearson correlation results are shown in Table 2. From the results, Non-financial Organizational Performance has positive and significant correlated with all of the independent variables which are top management support $(\mathrm{r}=0.647, \mathrm{p}<0.01)$, customer focus $(\mathrm{r}=0.353, \mathrm{p}<0.01)$, employee participation $(\mathrm{r}=0.595, \mathrm{p}<0.01)$, training and education $(r=0.403, p<0.01)$, continuous process improvement $(r=0.606, p<0.01)$, strategic planning $(\mathrm{r}=0.494, \mathrm{p}<0.01)$, effective communication $(\mathrm{r}=0.771, \mathrm{p}<0.01)$, and decision-making based on information $(\mathrm{r}=$ $0.578, \mathrm{p}<0.01)$.

Similarly customer focus is significantly and positively correlated top management support with both customer focus $(\mathrm{r}=0.583, \mathrm{p}<0.01)$, employee participation $(\mathrm{r}=0.621, \mathrm{p}<0.01)$, training and education $(\mathrm{r}=0.652, \mathrm{p}<0.01)$, effective communication $(\mathrm{r}=0.350, \mathrm{p}<0.01)$, and decision-making based information $(\mathrm{r}=0.317, \mathrm{p}<0.01)$, while positively and nonsignificant correlated with strategic planning $(\mathrm{r}=0.069, \mathrm{p}>0.05)$, and continuous process improvement $(\mathrm{r}=0.148, \mathrm{p}>0.05)$.

Following that, Customer focus is significantly and positively correlated with employee participation $(\mathrm{r}=0.441, \mathrm{p}<$ $0.01)$, training and education $(\mathrm{r}=0.523, \mathrm{p}<0.01)$, effective communication $(\mathrm{r}=0.375, \mathrm{p}<0.01)$, decision-making based on information $(r=0.310, p<0.01)$, strategic planning $(r=0.202, p<0.05)$, and nonsignificant correlated with continuous process improvement $(\mathrm{r}=0.128, \mathrm{p}>0.05)$. Subsequently, Employee participation is significantly and positively correlated with training and education $(\mathrm{r}=0.371, \mathrm{p}<0.01)$, continuous process improvement $(\mathrm{r}=0.320, \mathrm{p}$ $<0.01)$, strategic planning $(\mathrm{r}=0.405, \mathrm{p}<0.01)$, effective communication $(\mathrm{r}=0.408, \mathrm{p}<0.01)$, and $)$, decisionmaking based on information $(r=0.342, \mathrm{p}<0.01)$.

Consequently, training and education is significantly and positively correlated with continuous process improvement $(\mathrm{r}$ $=0.347, \mathrm{p}<0.01)$, effective communication $(\mathrm{r}=0.240, \mathrm{p}<0.01)$, strategic planning $(\mathrm{r}=0.184, \mathrm{p}<0.05)$, decisionmaking based on information $(r=0.190, \mathrm{p}<0.05)$.

Thus, Continuous process improvement is significantly and positively correlated with strategic planning $(\mathrm{r}=0.535, \mathrm{p}<$ 0.01), effective communication $(r=0.747, \mathrm{p}<0.01)$, and $)$, decision-making based on information $(\mathrm{r}=0.508, \mathrm{p}<$ 0.01).Therefore, strategic planning is significantly and positively correlated with effective communication $(r=0.642, p$ $<0.01)$, and $)$, decision-making based on information $(\mathrm{r}=0.589, \mathrm{p}<0.01)$.

Finally, with effective communication is significantly and positively association with decision-making based on information $(\mathrm{r}=0.745, \mathrm{p}<0.01)$. 
Table 3exhibits the simple linear regression analysis oriented to the relationship between total quality management Multidimensional and Non-financial Organizational Performance. According to the examined result of the regression analysis performed, it had been found that in the regression model, to be established indicates a statistical significance; since the statistical significance values of the $\mathrm{F}$ values are lower than 0.05 .

We run multiple linear regression models to test the hypothesized relationships. The results are shown in Table 3 Top management support $\left(\beta=0.464, p<0.05, R^{2}=0.419\right)$, Customer focus $\left(\beta=0.125, p<0.05, R^{2}=0.214\right)$, Employee participation $\left(\beta=0.350, p<0.05, R^{2}=0.355\right)$, Training and education $\left(\beta=0.200, p<0.05, R^{2}=0.162\right)$, Continuous process improvement $\left(\beta=0.351, p<0.05, R^{2}=0.3685\right)$, Strategic planning $\left(\beta=0.284, p<0.05, R^{2}=0\right.$. 244), Effective communication $\left(\beta=0.620, p<0.05, R^{2}=0.595\right)$, and Decision-making based on information $(\beta=0$. $337, \mathrm{p}<0.05, \mathrm{R}^{2}=0.334$ ), have significant positive effect on Non-financial Organizational Performance. Hence, all are supported.

Table 3 The relationship between the Non-financial organization performance and TQM Multidimensional

\begin{tabular}{llllllr}
\hline Independent variable & $\boldsymbol{\beta}$ & $\mathbf{t}^{*}$ & $\mathbf{P}^{* *}$ & $\mathbf{R}^{2}$ & Hypothesis & Result \\
\hline Top management support & .464 & 9.266 & .000 & .419 & $\mathrm{H} 1$ & Accepted \\
Customer focus & .214 & 4.115 & .000 & .125 & $\mathrm{H} 2$ & Accepted \\
Employee participation & .350 & 8.084 & .000 & .355 & $\mathrm{H} 3$ & Accepted \\
Training and education & .200 & 4.803 & .000 & .162 & $\mathrm{H} 4$ & Accepted \\
Continuous process improvement & .351 & 8.317 & .000 & .368 & $\mathrm{H} 5$ & Accepted \\
Strategic planning & .284 & 6.192 & .000 & .244 & $\mathrm{H} 6$ & Accepted \\
Effective communication & .620 & 13.228 & .000 & .595 & $\mathrm{H} 7$ & Accepted \\
Decision-making based on information & .337 & 7.729 & .000 & .334 & H8 & Accepted \\
\hline
\end{tabular}

Notes: *The tabulated value of $t=1.96 ; * *$ significant at $P<0.05$.

\section{Discussion}

The major aim of this paper was twofold; to empirically examine the impact of TQM multidimensional constructs, such as top management support, customer focus, employee participation, training and education, continuous process improvement, strategic planning, effective communication, and decision-making based on information on non-financial performance of organization; and to determine which TQM constructs are major predictor of non-financial organizational performance in hotels sector which are classified within the Saudi commission for tourism and national heritage (SCTH) in Najran Region. The findings show that the major predictor on non-financial organizational performance is effective communication followed by top management support, continuous process improvement, employee participation, decision-making based on information, strategic planning, training and education and finally by customer focus.

\subsection{Top management support}

Top management support is significantly associated with non-financial organizational performance. This finding is consistent with previous studies of Arumugam, Ooi, and Fong, (2008), they find positive relationship between top management support and quality performance. However, our finding is not consistent with previous studies of Choi and Eboch (1998), and Kannan and Tan (2005). These studies find that one of TQM practice namely leadership has nonsignificant relationship with quality performance and financial performance. According to Simatupang and White (1998) top management support assist as a positive foundation for the company's whole processes that eventually affect organizational performance in Saudia's hotel industry context, the top management promote effective decision making in quality implementation and maintenance for effective improvement of performance.

\subsection{Customer focus}

Customer focus is significantly related with non-financial performance of organization within hotel industry of a developing country like Saudia Arabia. This result is consistent with the previous studies where scholars find that TQM elements such as customer focus and customer satisfaction positively affects performance of organization ( Yasin, Kunt, \&Zimmerer , 2004). On the other hand, our results are not consistent with the other researches where researchers find that a customer orientation restrain the organizations to become a broad minded which stop their ability to innovate and prevent them to become a market leader (Prajogo and Sohal, 2001). They added that, customer focused organizations lead to high cost and associated risks which have adversative impact on their performance. Therefore, management of the organizations should take appropriate measures to maintain their customers. The management should also incorporate the quality related complaints of the customers so that their overall performance may be enhanced. 


\subsection{Employee participation}

Employee participation is significantly related with non-financial organizational performance. This result is consistent with the study of Butali, and Njoroge, (2018) which finds that employee participation had a significant effect on organizational performance. This finding is also consistent with Lorente, Dewhurst. and Dale (1999) where they recommend that well trained employees are open to bring favorite ideas for innovations and performance enhancement. Employee participation is a key dimension for successful TQM implementation, it has great importance in hospitality companies, where the international market is of extreme importance, andtherefore TQM implementation through various quality standards certifications is oftendemanded. This result is as per expectations, teamwork and supportive employeemanagement techniques increases efficiency and problem solving abilities of employeesthat ultimately accumulate into organizational performance ( Anschutz,1995).

\subsection{Training and education}

Training and education was discovered to be significant and positively related to non-financial organizational performance. Nevertheless , this outcome is inconsistent with the findings of Zhang (2000) and Ooi, Arumugam, , Teh, and Chong, (2008). Training and education is very critical and management have to understand that there activities lead to long-term commitment, as the finding of TQM implementation are not realized immediately. It was also found that training and education has more positive effects on service industries employees rather than manufacturing industries employees (Zhang, 2000). As per Cherrington (1995), in order to minimize TQM barriers like employee nonattendance and high-turnover rate, and when employees are not satisfied, top-management suggest a company-wide training program.

\subsection{Continuous process improvement}

Continuous process improvement is significantly associated with non-financial organizational performance. This result is consistent with previous studies where researchers find that the continuous improvement in quality standards has positive influence on various styles of performance (Fuentes, Montes, \& Fernandez, 2006; Rahman \& Bullock, 2005; Sadikoglu\&Zehir, 2010). Keeping in view the importance of continuous activities improvement in TQM implementation makes quality management more relevant for service firms. This may be a reason that most of the previous studies in this field have selected the service contexts for testing of their hypotheses. However, particularly hotel sector has rarely been contextualized for this purpose. This finding in the context of the present study (i.e. hotel industry of a Saudi Arabia) suggests a convergence trends on the phenomenon understood and predicted through this result.

\subsection{Strategic planning}

It was also discovered that strategic planning is significantly associated with non-financial organizational performance . It can be said that performance of an organization will increase when anorganization implements strategic planning process comperhensively. This due to the fact that the present studies finding is similar with the Ramli, Zen, Mustafa,. \&Yusoff, (2017), In the same time, there are diverse reason why strategic planning could drive to better organizational performance. I t obviously by having strategic planning, an organization's trend to becomes clear. As a consequence of that, an organization can develop various strategies to achieve their goals. Meanwhile other researchers argue that strategic planning of an organization can also lead to high quality services, and better organizational performance (Bryson, 2011; Poister\&Streib ,2005).

\subsection{Effective communication}

Effective communication is significantly associated with non-financial organizational performance. However, this outcome is inconsistent with the findings of Talib, Rahman, and Qureshi (2013). Active communication among the employees will increase their, knowledgeable, skillful, motivated, quality oriented, and attitude, and all that when happened the employees performance will improved (Allen and Kilmann, 2001).

\subsection{Decision-making based in information}

Finally, decision-making based in information have a significant and positively related to non-financial organizational performance. Nevertheless , this outcome is inconsistent with the findings of (Al-Damen, 2017). Effective decisions based on data and information analysis are achieved by taking measurements and collecting data and information related to the purpose, and to ensure the accuracy and validity of the data, information, and easy access to, and analysis of data and information methods, and realize the importance of using appropriate statistical techniques, and decision making builds on the results of logical analysis (Al-Damen, 2017).

Based on the above discussion we can conclude that the current study accomplishes its main objectives. The study reveals the importance of TQM multidimensional constructs and non-financial organizational performance in Saudia's hotel sector. In response of the fourfold TQM dimensions and non-financial organizational performance objectives of 
the study, the analytical results confirm the significant and positive association of eight TQM dimensions (top management support, customer focus, employees' participation, training and education, continuous process improvement, strategic planning, effective communication, and decision-making based on data and information) with non-financial organizational performance. Furthermore, it is empirically determined that TQM dimensions such as these four TQM dimensions are major predictors of performance of hotel sector in Saudi Arabia's Najran region.

\section{Limitations and Future Directions}

We highlight some limitations of this study that should be focused for future improvements. First, it is a cross-sectional study as the data is collected at one point of time may sustain from response biases. Second, this study focuses only on hotel service sector; hence its results may not be generalized to all other sectors such as manufacturing sector.

The third limitation of the study is that, although the source of data for the TQM multidimensional constructs (independent variable) is different from that of the non-financial organizational performance (dependent variable), both variables are measured on the perceptional data provided by the managers. However, the aggregation of responses of two or more employees for each of the study variable mitigates this problem.

In Future, in order to transform quality certifications into performance enhancement, changes should be monitored with several times of data (longitudinal study). Future research should be conducted out on some other industries in manufacturing sector as well as service organizations. Future research should attempt to investigate the mediators such as organizational learning capability and market orientation in order to understand TQM- performance relation. In future, for better understanding of TQM and performance relationship, the mediating mechanism may be tested with the help of structural equation modeling (SEM).

\section{Implications}

Such an empirical examination of the relationship between TQM multidimensional constructs and non-financial organizational performance in hotel industry sector of Saudi Arabia is likely to be useful for academia and practitioners in our context. From theoretical perspective, the study provides a comprehensive understanding of TQM dimensions to enhance non-financial organizational performance within hotel sector of Saudi Arabia. The study provides a theoretical framework that will help the academicians to formulate the strategies for maximizing the influence of TQM multidimensional constructs for enhancing non-financial organizational performance. For managerial perspective, the study suggests that managers of manufacturing firms who intend to achieve higher organizational performance through the implementation of TQM must focus on continuous improvement and employee involvement. The current study empirically proves that eight TQM variables such as top management support, customer focus, employee participation, training and education, continuous process improvement, strategic planning, effective communication, and decisionmaking based on data and information are key predictors of non-financial performance organizational performance. Thus, the practitioners of manufacturing organizations should give more concentration to these eight multidimensional constructs of TQM while implementing and managing TQM to attain better non-financial performance.

\section{References:}

Abu Ziadeh, Z. A. (2011). Effect of applying TQM concept to organizational performance: An applied study in a sample of Palestinian commercial banks, An-Najah National University for Research Journal (Human Sciences), 25, 4.

Ahire, S., Golhar, D., \& Waller, M. (1996) . Development and Validation of TQM Implementation Constructs. Decision Sciences, 27(1), 23-56. http://dx.doi.org/10.1111/j.1540-5915.1996.tb00842.x

Butali, P.\&Njoroge, D. (2018). Effect of Employee Participation on Organizational Performance with Organizational Commitment as a Moderator, International Journal of Scientific Research and Management (IJSRM), Volume 06, Issue 06, PP.478-485.

Ahire, S., Golhar, D., \& Waller, M. (1996). Development and Validation of TQM Implementation Constructs. Decision Sciences, 27(1), 23-56. http://dx.doi.org/10.1111/j.1540-5915.1996.tb00842.x

Ahire, S., Golhar, D., \& Waller, M. (1996). Development and Validation of TQM Implementation Constructs.

Decision Sciences, 27(1), 23-56. http://dx.doi.org/10.1111/j.1540-5915.1996.tb00842.xAhire, S., Golhar, D., \& Waller, M. (1996). Development and Validation of TQM Implementation Constructs. Decision Sciences, 27(1), 23-56. http://dx.doi.org/10.1111/j.1540-5915.1996.tb00842.x

Al-Damen, R. A. (2017) The impact of Total Quality Management on organizational performance Case of Jordan Oil Petroleum Company, International Journal of Business and Social Science, Vol. 8, No. 1, PP.192-202.

Allen, R.S. and Kilmann, R.H. (2001) The role of the reward system for a total quality management based strategy. Journalof Organizational Change Management, 14, 110-131. 
Al-Qudah, K. A. M. 2012. "The Impact Of Total Quality Management On Competitive Advantage Of Pharmaceutical Manufacturing Companies In Jordan," Perspectives of Innovation in Economics and Business (PIEB), Prague Development Center, vol. 12(3), pages 59-75, November.

Amabile, T. M. (1988). A model of creativity and innovations in organizations. In B. M. Staw\& L. L. Cummings (Eds.), Research in organizational behavior, vol. 10: 123-167. Greenwich, CT: JAI Press.

Anschutz, E.E. (1995), TQM America: How America's Most Successful Companies Profit from Total Quality Management, McGuinn\& McGuire, Bradenton, FL.

Antony, J., Leung, K., Knowles, G. and Gosh, S. (2002), "Critical success factors of TQM implementation in Hong Kong industries”, International Journal of Quality \& Reliability Management, Vol. 19 No. 5, pp. 551-66.

Arumugam, V., Ooi, K. B. and Fong, T. C. (2008). TQM practices and quality management performance: An investigation of their relationship using data from ISO 9001:2000 firms in Malaysia. The TQM Journal, 20(6), 636-650.

Babakus, E., (1996), The Practice of Social Research. 3rd Ed. Wadsworth Publishing Company.

Barney, J. (1991) Firm Resources and Sustained Competitive Advantage. Journal of Management, 17, 99-120.

Benavent, F. B., Ros, S. C., \& Moreno-Luzon, M. (2005). A model of quality management self-assessment: An exploratory research. International Journal of Quality \& Reliability Management, 22(5), 432-451.

Benkhoff, Birgit, 1997, "Ignoring Commitment is Costly: New Approaches Establish the Missing Link Between Commitment and Performance," Journal of Human Resources, Vol 50. No. 6.

Bery, B, Otieno,A, Waiganjo, E.W \&Njeru, A (2015). Effect of Employee Communication on Organisation Performance: in Kenya's Horticultural Sector. International Journal of Business Administration, 6(2),138-145 Retrieved from, http://dx.doi.org/10.5430/ijba.v6n2p138.

Bryson, J., 2011. Strategic Planning for Public and Nonprofit Organizations: A Guide to Strengthening and Sustaining Organizational Acheivement. $3^{\text {rd }}$ Edn, Jossey Bas, San Francisco, California, ISB:98-0470-39251, Pages: 549.

Cheng and Kalleberg Chen, Li Yueh, 1996, "Examining The Effect Of Organization Culture And Leadership Behaviors On Organizational Commitment, Job Satisfaction, Job Performance Adan At Small And Middle-Sized Firm Of Taiwan, "Journal of American Academy of Business, Sep 2004 , 5, 1/2, 432-438.

Cherrington, D.J. (1995), The Management of Human Resources, Prentice-Hall, Englewood Cliffs, NJ.

Choi, T.Y. and Eboch, K. (1998). The TQM paradox: Relations among TQM practices, plant performance and customer satisfaction. Journal of Operations Management, 17(1), 59-75.

1Corbett, L. \&Rastrick, K. (2000), "Quality performance and organizational culture”, International Journal of Quality \& Reliability Management, Vol. 17 No. 1, pp. 14-26.

Dooyoung, S., Kalinowski, J.G. and El-Enein, G. (1998). Critical implementation issues in total quality management. SAM Advanced Management Journal, 63(1), 10-14.

Evans, J.R. (1991), Creative Thinking: In the Decision and Management Sciences, Cininnate: South- Western Publishing Co.

Ferdinand, A. (2004). Sales Management Dynamics: A Conceptual Model Test for Direct Selling ". Journal of Economics and Business, vol. X, no.1, pp. 17-38.

Field, A. (2009). Discovering Statistics Using SPSS. 3rd Edition, Sage Publications Ltd., London.

1Flynna, B. B., Schroederb, R. G., \&Sakakibara, S. (1994). A framework for quality management research and an associated measurement instrument. Journal Operation Management, 11: 339-366. DOI: 10.1016/S02726963(97)90004-8.

Fuentes, M.M.F., Montes, F.J.L. and Fernandez, L.M. (2006). Total quality management, strategic orientation and organizational performance: the case of Spanish companies. Totalquality management, 17(3), 303-323.

1Hackman, J.R. \&Wageman, R. (1995), "Total quality management: empirical, conceptual, and practical issues", Administrative Science Quarterly, Vol. 40, pp. 309-42.

Hair, Jr., Yoseph, F., Rolph, E., Anderson, R.L.P. and Black W. (1998). Multivariate Data Analysis (5th Edition). New Jersey: Prentice-Hall, Inc.

Hoang, D. T., Igel, B. \&Laosirihongthong, T. (2006). The impact of total quality management on innovation: findings from a developing country. International Journal ofQuality and Reliability Management, 23(9), 1092-1117.

Hooley, G., Fahy, J., Greenley, G., \&Beracs, J. e. a. (2003). Market orientation in the service sector of transition economies of Central Europe. European Journal of Marketing, 37, 86-107.

Hung, H.M. (2007). Influence of the environment on innovation performance of TQM. Total Quality Management, 18(7), 715-730.

ISO (2000), "EN/ISO 9001:2000 Quality Management Systems: Requirements", International Organization for Standardization, Geneva. 
Ittner, C. D., \& D. F. Larcker. (1996). Measuring the impact of quality initiatives on firm financial performance. Advances in the Management of Organizational Quality 1: 1-37.

Joiner, T. A. (2007). Total Quality Management and Performance: The Role of Organization Support and Co-worker Support. International Journal of Quality \& Reliability Management. Vol. 24 No. 6, pp. 617-627.

1Jun, M., Cai, S. and Shin, H. (2006). TQM practice in Maquiladora: antecedents of employee satisfaction and loyalty. Journal of Operations Management, 24 (6), 791-812.

Jusoh, R., Ibrahim, D. N., \&Zainuddin, Y. (2008). The performance consequence of multiple performance measures usage: Evidence from the Malaysian manufacturers. International Journal of Productivity and Performance Management, 57(2), 119-136.

Kannan, V.R. and Tan, K.C. (2005). Just in time, total quality management, and supply chain management: understanding their linkages and impact on business performance. Omega, 33(2), 153-162.

Kibe, C.W. (2014). Effects of Communication Strategies on Organizational Performance: A Case Study of Kenya Ports Authority.European Journal of Business and Management 6(11) 6- 10. Retrieved from www.iiste.org.

1Lewis, W.G., Pun K.F. and Lalla, T.R.M. (2005), "An AHP-based study of TQM benefits in ISO 9001 certified SMEs in Trinidad and Tobago, The TQM Magazine, Vol. 17, No.6, pp. 558-572.

Locke, E. A., \&Schweiger, D. M. (1979). Participation in decision-making: One more look. In B. M. Staw (Ed.), New directions in organizational behavior, vol. 1: 265-339, Greenwich, GT: JAI Press.

Lorente, A.R.M., Dewhurst, F. \& Dale, B.G. (1999). TQM and Business Innovation”, European Journal of Innovation Management, 2(1), 12-19.

Luthans, F. (1989) Organizational Behavior. 5th Edition, McGraw-Hill Inc., New York. management and Peter Senge's disciplines of a learning organization: A Taiwan perspective.

Melhem, Y. S. (2006). Effect of Organizational Climate on Job Satisfaction Case Study: Modern Jordanian Communications Company, Arab Journal of Management, 26 (2),3-39.

Miranda, A. (2003). Total Quality Management and Inequality: The triple helix in global Historical perspective. Science, Technology \& Human Values, 28(1), 34-51.

MosammodMahamudaParvin, M.M.N.K. (2011) Factors Affecting Employee Job Satisfaction of Pharmaceutical Sector. Australian Journal of Business and Management Research, 1, 113-123.

Nayla B. E., and Ridzuan M. (2014). Understanding Impact of Financial and Non-Financial Measurements in Sudanese Banks' Performance. International Journal of Humanities and Management Sciences (IJHMS) Volume 2, Issue 3, 98-104.

Ngambi, M., T., \&Nkemkiafu, A. G. (2015). The impact of Total Quality Management on Firm's Organizational Performance. American Journal of Management, 15(4), 69.

Oakland, J.S. (1989). Total Quality Management, Heinemann Professional, London,

1110oi, K.-B., Arumugam, V., Safa, M.S. and Bakar, N.A. (2007). "HRM and TQM: association with job involvement", Personnel Review, Vol. 36 No. 6, pp. 939-62.

Ooi, K.-B., Arumugam, V., Teh, P.-L. and Chong, A.Y.-L. (2008), "TQM practices and its association with production workers”, Industrial Management \& Data Systems, Vol. 108, No. 7, pp. 909-27.

Pearce, J.L. \&Gregersen, H.B. (1991). "Task Interdependence and Extra- role behavior: A test of the Mediating Effects of felt Responsibility". Journal of Applied psychology. 76 (6) .838-844.

Podsakoff, P.M., MacKenzie, S.B., Podsakoff, N.P. and Lee, J.Y. (2003). Common method biases in behaviors research: A critical review of the literature and recommended remedies. Journal of Applied Psychology, 88(5), 879-903.

Poister, T.H. \& G. Streib, 2005. Elements of strategic planning and management in municipal government: Status after two decades. Public Administrative Rev., 65:45-56.

Porter, M.E. (1979) How Competitive Forces Shape Strategy. Harvard Business Review, 57, 137-145.

Prajogo, D.I. \&Sohal, A.S. (2001). TQM and Innovation: A Literature Review and Research Framework, Technovation, 21(9), 539-558.

Quinn, J. J., \&Goold, M. (1990). "The Paradox of Strategic Controls”. Strategic Management Journal, vol.11, pp. 4357.

1Ramli, R., Zen, M. Mustafa, M. \&Yusoff, R.Z. (2017), Strategic Planning Organizational Performance in the Public Sector: A Study of Local Government in Aceh, Indonesia, The Social Sciences,12,(16), PP. 902-906.

1Reed, R., Lemak, D. J., \& Mero, N. P.(2000). Total Quality Management and sustainablecompetitive advantage. Journal of Quality Manage., 5(1), pp. 5-26.

11Sadikoglu, E. and Zehir, C. (2010), "Investigating the effects of innovation and employee performance on the relationship between TQM practices and firm performance: an empirical study of Turkish firms", International Journal of Production Economics, Vol. 127 No. 1, pp. 13-26. 
Saudi Commission For Tourism and National Heritage (SCTH) (2018), Tourism Accommodation, List of licensed establishments, available at :https://scth.gov.sa/TourismInvestment/TourismLicensing/Pages/Hotel5List.aspx.

Savills (2016). Saudi Arabia Hotel Market, Demand drives hotel growth, cited 2019 August 19, 10: 10 am. Available from: https://dubai.savills.ae/research-and-news/saudi-arabia-hotel-report.pdf

1Sayyad, N. (2017), The Relationship between Total Quality Management Practices and Their Effects on Firms Performance in Palestine Business \& Entrepreneurship Journal, vol. 6, no. 2,PP.35-51.

Schalk, R. \&Dijk, W. V., (2005), "Quality management and employee commitment illustrated with examples from Dutch health care", International Journal of Health Care Quality Assurance, Vol. 18(3), p. 170-178.

Shah, A. (2009). Global financial crisis 2008. http://www.globalissues.org/article/768/ global-financial-crisis Accessed 18.01.09.

Shenawy, E .E., Baker, I. \&Lemak, D. J. (2007). A metal-analysis of the effect of TQM on competitive advantage. International Journal of Quality \& Reliability Management, 24(5), 442-471.

Sherisheer, S. S. M., (2000). Job satisfaction with managers' departments in the ministries of the Palestinian National Authority who is working in the governorates of Northern Palestine (unpublished master thesis), College of Graduate Studies, An-Najah National University, Nablus, Palestine. Retrieved from: http://search.mandumah.com/Record/545150.

Simatupang, T.M. and White, A.J. (1998). A policy resolution model for knowledge acquisition in quality management. Total Quality Management, 9(8), 767-779.

Singh, V., Kumar, A., \& Singh, T. (2018). "Impact of TQM on organizational performance: The case of Indian manufacturing and service industry," Operations Research Perspectives,Elsevier, vol. 5(C), pages 199-217.

Tabachnick, B. G., \&Fidell, L. S. (2007). Using multivariate statistics (5th ed.). Boston, MA, : Allyn \& Bacon/Pearson Education.

Talib, F. \& Rahman, Z. (2010), "Critical success factors of total quality management in service organization: a proposed model”, Service Marketing Quarterly, Vol. 31 No. 3, pp. 363-80.

1Talib, F., Rahman, Z. \& Qureshi, M. N. (2013), "An empirical investigation of relationship between total quality management practices and quality performance in Indian service companies”, International Journal of Quality and Reliability Management, Vol. 30, No.3, pp. 280-318.

Teh, P.-L., Yong, C.-C., Arumugam, V. \&Ooi, K.-B. (2009), "Does total quality management reduce employees' role conflict?”, Industrial Management \& Data Systems, Vol. 109 No. 8, pp. 1118-36.

Terziovski, M., Sohal, A. \& Samson, D. (1996). Best practice implementation of total quality management: Multiple cross-case analysis of manufacturing and service organizations. Total Quality Manage., 7: 459-481. DOI:10.1080/09544129610586.

Venkatraman, N., Ramanujam, V. (1986). Measurement of business performance in strategy research: a comparison of approaches. Academy of Management Review, 11(4), 801-814.

WTTC, (2019). worldtravel \& tourism power and performance report, cited 2019 July 5, 8: 10 am. Available from: https://www.wttc.org/-/media/files/reports/2018/power-and-performance-rankings-2018.pdf

Yasin, M. M., Kunt, J. A. M., \&Zimmerer, T. W. (2004). TQM practices in service organizations: An exploratory study into the implementation, outcomes and effectiveness. Managing Service Quality, 14(5), 377-389.

Yusuf, Y., Gunasekaran, A. \& Dan, G. (2007). "Implementation of TQM in China and organizational performance: an empirical investigation”, Total Quality Management, Vol. 18 No. 5, pp. 509-30.

Zahedi, F.M., 1998. Quality information systems: A unifying framework. International Journal Technology Management, 16: 446-465. DOI: 10.1504/IJTM.1998.002683.

Zakuan, N.M., Yusof, S.M., Laosirihongthong, T. \&Shaharoun, A.M. (2010), "Proposed relationship of TQM and organizational performance using structured equation modeling”, Total Quality Management, Vol. 21 No. 2, pp. 185-203.

Zhang, Z., Waszink, A. and Wijngaard, J. (2000), "An instrument for measuring TQM implementation for Chinese manufacturing companies", International Journal of Quality \& Reliability Management, Vol. 17 No. 7, pp. 730-55.

1 Zhang, Z.H. (2000). Implementation of total quality management: an empirical study of Chinese manufacturing forms (PhD unpublished thesis). Groningen: University of Groningen.

Zhou, J. \& George, J. (2001). "When job Dissatisfaction leads to Creativity: Encouraging the Expression of Voice ". Academy of Management Journal. 44 (4). 682-696. 